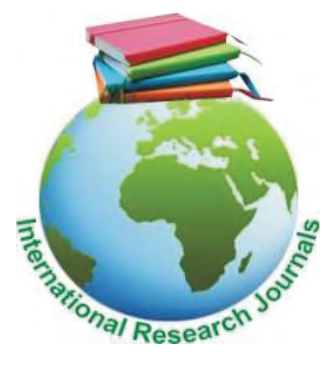

\title{
Antimicrobial Properties, Phytochemical Composition, and Phenotypic Resistance Pattern of Selected Enteropathogenic Microorganism on Ageratum conyzoides (Goat Weed) Leaf Extract
}

\author{
Oludare Temitope Osuntokun $^{*}$, Taiye A. Jemilaiye ${ }^{2}$, A. M. Yusuf-Babatunde ${ }^{3,4}$, Akele E.O \\ ${ }^{1-3}$ Department of Microbiology, Adekunle Ajasin University, Akungba Akoko, Nigeria \\ ${ }^{4}$ Department of Pharmaceutical Technology, Ogun State College of Health Technology, Ondo state, Nigeria \\ *Corresponding e-mail: oludare.osuntokun@aaua.edu.ng
}

\begin{abstract}
The aim of this study is to determine the phytochemical composition, antimicrobial properties and phenotypic resistance pattern of selected enteropathogenic microorganism on Ageratum conyzoides leaf extract. Enteropathogenic isolates were collected from Adekunle Ajasin University Health Centre, Akungba Akoko, Ondo State and were identified using Microbact ${ }^{\mathrm{TM}}$ 24E Identification kit. Antibiotic sensitivity testing was carried out against the enteropathogenic organism using Kirby-Bauer disc diffusion method, imipenem was active against Proteus mirabilis, Enterobacter agglomerans, Enterobacter gerogoviae, with diameter zone of inhibition of 41 $\mathrm{mm}, 26 \mathrm{~mm}$ and $30 \mathrm{~mm}$. ofloxacin were active against Proteus mirabilis, Enterobacter agglomerans, Enterobacter gergoviae, with diameter zone of inhibition of 21, 31 and $21 \mathrm{~mm}$. All enteropathogenic organisms shows high resistant rate against oxacilin, vancomycin, amoxicillin, ceftazidime, piperacillin, cefoxitin, tazobactam. Antimicrobial screening of the leaf extract of Ageratum conyzoides revealed high bioactivity against Serratia marcescens, Proteus vulgaris, Enterobacter agglomerans and Proteus mirabilis isolates with diameter zone of inhibition ranging from $15 \mathrm{~mm}$ to $22 \mathrm{~mm}$ at $100 \mathrm{mg} / \mathrm{ml}$. Using broth dilution method, the minimum inhibitory concentrations (MIC) of the Ageratum conyzoides (Goatweed) extract range from $25 \mathrm{mg} / \mathrm{ml}$ and $100 \mathrm{mg} / \mathrm{ml}$. The phytochemical screening results shows that Ageratum conyzoides extract contained alkaloid, pholobotannins, Cardiac glycoside, phenol, tannins, saponin, and flavonoids. It can be deduced from this research work that Ageratum conyzoides has better antimicrobial properties and it contains very important phytochemical constituents which can be a magic bullet to deal with the menace of antimicrobial resistance enteropathogenic microorganism.
\end{abstract}

Keywords: Antimicrobial properties, Ageratum conyzoides, Phenotypic resistance pattern, Enteropathogenic bacteria

\section{INTRODUCTION}

Ageratum conyzoides (Billy goat-weed, Chick weed, Goat weed, White weed; Ageratum conyzoides L., Ageratum obtusifolium Lam., Cacaliamentrasto Vell) is native to tropical America, especially Brazil. The herb 0.5-1 m. high, with ovate leaves $2-6 \mathrm{~cm}$ long, and flowers are white to mauve. In Vietnamese, the plant is called curtlon (Pig faeces) due to its growth in dirty areas. The plant belongs to the order asterales, family asteraceae, tribe eupatorieae, genus Ageratum, and species conyzoides. It is a common weed, having spread from its native range to all areas of the Tropics within $20^{\circ}$ of the Equator to an altitude of 2,500 metres.

The leaves and the flowers yield $0.2 \%$ with a powerful nauseating odour. The oil contains $5 \%$ eugenol, which has a pleasant odour. The oil from plants growing in Africa has an agreeable odour, consisting almost entirely of eugenol. A decoction of the fresh plant is used as a hair wash, leaving the soft, fragrant and dandruff-free (Adak et al., 2002). The plant survived in full sun and under sheltered position in any reasonably 
fertile moisture retentive soil that does not dry out in the summer. Plant vigour and flowering period are much reduced on dry soils. This species is not frost hardy, though it can be grown as a summer annual in Britain (Akinyemi et al., 2005). Ageratum conyzoides can complete its life cycle in less than two months. Although it can flower when less than two months, true leaves have expanded, it is more commonly to seen in favourable conditions as a well-branched plant up to $9 \mathrm{~cm}$ tall with hundreds of flower heads (Chanda et al. 2006). Antimicrobial resistance is one of the world's most serious public health problems, many of the microbes (bacteria, viruses, protozoa) that cause infectious disease no longer respond to common antimicrobial drugs.

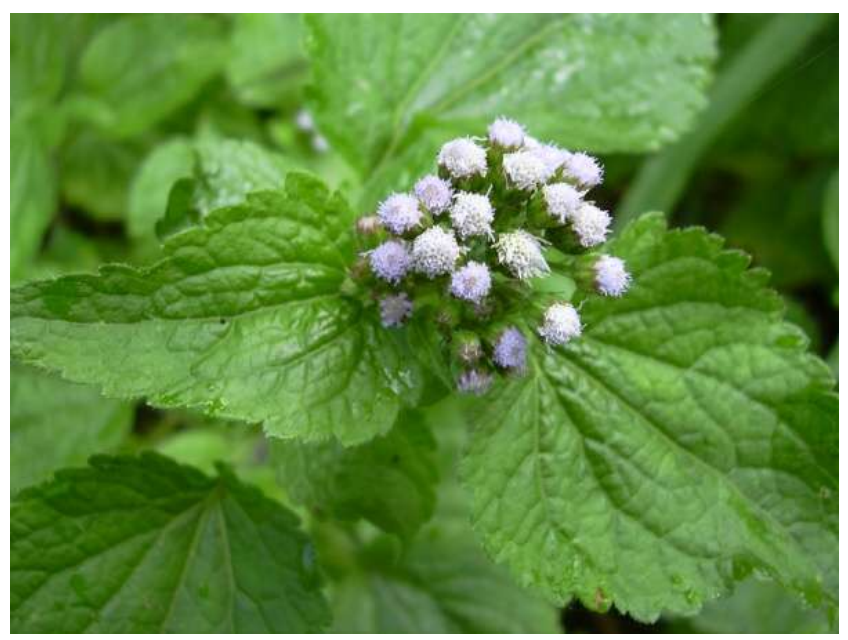

Figure 1. Ageratum conyzoides leaf.

The problem is so serious that unless concerted action is taken worldwide, we run the risk of returning to the pre-antibiotic era when many more children than now died of infectious diseases. The major infectious diseases kill over 11 million people per year. The prevalence rate of antimicrobial resistance all overall the world of diarrheal shigellosis is $10-90 \%$ for ampicillin and 5-95\% for trimethoprim/ sulfamethoxazole (Dandekar et al., 2010). For this reason the microbial antibiotics resistance is receiving increasing attention in light of the increasing incidence of human bacterial infections resistant to antibiotic treatment (Dahiru et al., 2006). The resistance of enteropathogenic bacteria to commonly prescribed antibiotics is increasing both in developing as well as in developed countries; resistance has emerged even to newer, more potent antimicrobial agents and is commonly seen in organism like Salmonella, Shigella, Vibrio cholerae (Darudoal 2006).

Multiple-drug resistant organisms (MDRO) are defined as bacteria that have become resistant to more than one class of antimicrobial agents and usually are resistant to all but one or two commercially treatment of illness they cause. The emergence of MDRO is increasingly recognized as a major public health threat based on data from the centres for Disease Control and Prevention (DCP) costing the United States Healthcare system approximately 3.2billion dollars annually with increasing mortality rates (Edeoga et al., 2005). Currently, two-thirds of all health careassociated infections (HAls) are caused by just six MDRO referred to by the acronym ESKAPE: Enterococcus species (vancomycin-VISA/VERSA), Klebsiella pneumonia, Acinetobacter baumanni, Pseudomonas aeruginosa and Enterobacter species (extended-spectrum beta-lactamase-producing gramnegative bacilli-ESBLs and fluoroquinolone-resistant $P$. aeruginosa) (Hazra et al., 2007).

\section{MATERIAL AND METHODS}

\section{Description of the Study Area}

The study area was Adekunle Ajasin University Health Akungba Akoko, Ondo State, Nigeria. The study was conducted between October 2017 and June 2018. Patients from Adekunle Ajasin University Health Centre Akungba Akoko, one of the major Towns in Ondo State. Ondo State lies between latitude $5^{\circ} 45^{\prime}$ and $8^{\circ} 15^{\prime}$ North and longitude $4^{\circ} 45^{\prime}$ and $6^{\circ}$ East were used for this research work (Kamboj et al., 2008).

\section{Collection and Processing of Samples}

A total of 20 stool samples were collected from patients with acute diarrhoea (Gastroenteritis). About five to ten grams (or millilitres) fresh stool samples without any preservatives were collected in sterile plastic universal specimen bottles. All stool samples were transported to the laboratory in the sterile container, and all the stool specimens are stored at $-20^{\circ} \mathrm{C}$ freezer for further analysis. Samples were completely labelled by the necessary data (date, time of collection, sample type, patient name).

\section{Test Organisms}

The test organisms used were standard strains of pathogenic enteric bacteria isolates. They including Proteus vulgaris, Stenotrophomonas maltophilia, Hafnia alvei, Proteus mirabilis, Serratia marcescens, Enterobacter agglomerans, Citrobacter freundii, Proteus Iuminescence, Samonella substilis, Serratia rubidaea and Enterobacter gergoviae as they are identified via microbat ${ }^{\mathrm{TM}} 24 \mathrm{E}$ identification kit. The bacterial isolates were cultured in slanted Mueller Hinton agar and transported at a low temperature to Microbiology Laboratory, Adekunle Ajasin University, Akungba-Akoko, Ondo State and incubated in an incubator for reactivation of the bacteria. They were then sub-cultured and stored $-4^{\circ} \mathrm{C}$ prior to bioassay of the extracts (Kumar et al., 2007). 


\section{Identification of the Enteropathogenic Bacterial Isolates}

The enteropathogenic bacterial isolates were identified using their colony morphological characteristics. The appearance of each colony on the agar media and characteristics such as shape, edge, colour, elevation and texture were observed as described by (Mcarvalho et al., 2010). The isolates were there after subjected to relevant biochemical tests and identified using the taxonomic scheme of Bergey's Manual of Determinative Bacteriology and Microbact $^{\mathrm{TM}}$ 24E identification kit test

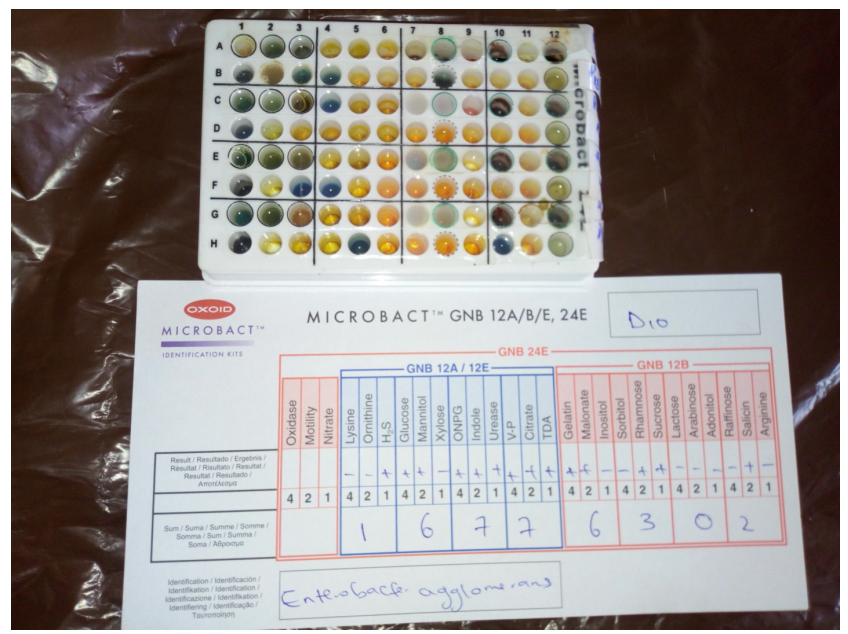

Figure 2. Microbact $^{\mathrm{TM}}$ 24E identification kit result for isolated bacteria.

\section{Standardization of Test Organisms}

Slants of the various organisms were reconstituted at aseptic conditions; using a sterile wire loop approximately one isolated colony of each pure culture was transferred into $5 \mathrm{ml}$ of sterile nutrient broth and incubated for 24 hours. After incubation, $0.1 \mathrm{ml}$ of the isolated colony was transferred into $9.9 \mathrm{ml}$ of sterile distilled water contained in each test tube using a sterile needle and syringe, and the mixed properly. The liquid now serve as source of inoculums containing approximately $106 \mathrm{cfu} / \mathrm{ml}$ of bacterial suspension (Metchock et al., 2011, Milstone et al., 2010).

\section{Antibiotic Susceptibility Test for the Bacterial Isolates}

Single disc diffusion method were employed as described by Bauer, was used to examine bacterial susceptibility to antimicrobial agents. The antibiotic sensitivity discs used were oxacillin $(1 \mu \mathrm{g})$, imipenem (10 $\mu \mathrm{g})$, vancomycin (30 $\mu \mathrm{g})$, amoxicillin (30 $\mu \mathrm{g})$, ceftazidime $(30 \mu \mathrm{g})$, ofloxacin $(5 \mu \mathrm{g})$, piperacillin (100 $\mu \mathrm{g})$, cefoxitin (30 $\mu \mathrm{g})$ and tazobactam (110 $\mu \mathrm{g})$ (Becton Dickson, USA). Single bacterial colonies from overnight culture were suspended in $5 \mathrm{ml}$ normal saline. The surface of Mueller Hinton agar plates was evenly inoculated; the antibiotics discs were applied on the surface of the inoculated agar plates with sterile forceps. Each disc was gently pressed down onto the agar to ensure complete contact with the agar surface; plates were incubated at $370^{\circ} \mathrm{C}$ for 24 hours. After incubation, the plates were examined and the diameter of the zones of inhibition was measured. Susceptibility data were interpreted according to the Clinical and Laboratory Standard Institute (Onwukaeme et al., 2007, Osuntokun 2015).

\section{Plant Sample- Source and Collection of Plant Sample}

The leaves of Ageratum conyzoides used in this study were collected from the campus environment, Adekunle Ajasin University Akungba Akoko, Ondo State, Nigeria.

Authentication of plant sample: the plants were authenticated at the Department of Plant Science and Biotechnology, Adekunle Ajasin University, AkungbaAkoko, Ondo State, Nigeria.

Preparation of plant sample: The leaves of Ageratum conyzoides after collection were first washed thoroughly with sterile distilled water to lose contamination and appropriately air dried at room temperature for two weeks to ensure the sample loss of their moisture content. The leaves of Ageratum conyzoides after being air dried, was milled to powder at the Department of Microbiology Laboratory, Adekunle Ajasin University, Akungba-Akoko, Ondo State, Nigeria.

Preparation of plant extracts: Five hundred gram (500 g) of the fine powder plant (Ageratum conyzoides) was weighed into corked container containing $1500 \mathrm{ml}$ of dichloromethane, the mixture were initially shaken vigorously and left for 7 Days. Mixture was filtered using whatman filter (No 1) papers, and the filtrates were collected directly into sterile crucibles. The filtrate was extracted using rotary evaporator, and the residues obtained were kept at room temperature (Metchock et al., 2011).

Standardization of plant extracts: At aseptic condition, the extracts are reconstituted by adding $1 \mathrm{~g}$ of extract, $2.5 \mathrm{ml}$ of Dimethyl sulfoxide (DMSO) and $7.5 \mathrm{ml}$ of sterile distilled water, making it $100 \mathrm{mg} / \mathrm{ml} .5 \mathrm{ml}$ of distilled water is measured into four bijou sterile bottles. In bijou bottle, a $5 \mathrm{ml}$ from the $100 \mathrm{mg} / \mathrm{ml}$ was drawn and added, making it $50 \mathrm{mg} / \mathrm{ml}$. The serial concentration was prepared to get concentrations of $100 \mathrm{mg} / \mathrm{ml}, 50 \mathrm{mg} / \mathrm{ml}, 25 \mathrm{mg} / \mathrm{ml}$ and $12.5 \mathrm{mg} / \mathrm{ml}$ respectively (Mcarvalho et al., 2010, Olajubu et al., 2015).

Antimicrobial assay of the plant extracts: Susceptibility screening test using agar well diffusion method, all the test bacteria, were sub-culture onto sterile Molarity 
agar plates, and incubated at $37^{\circ} \mathrm{C}$ for 24 hours, five distinct colonies for each organisms were inoculated for 3-4 hours. All inocula were standardized accordingly to match the 0.5 McFarland standards and this standard was used for all susceptibility tests. The leaf extracts were reconstituted accordingly into the following concentrations; $100 \mathrm{mg} / \mathrm{ml}, 50 \mathrm{mg} / \mathrm{ml}, 25$ $\mathrm{mg} / \mathrm{ml}$, and $12.5 \mathrm{mg} / \mathrm{ml}$, using Dimethyl sulfoxide (DMSO). $0.1 \mathrm{ml}$ of 1:10,000 dilutions (equivalent to106 $\mathrm{cfu} / \mathrm{ml}$ ) of fresh overnight culture of the enteric bacteria isolates grown in Nutrient broth was seeded into $40 \mathrm{ml}$ of Molarity agar, and properly mixed in universal bottles. The mixture was aseptically poured into petri dishes and allowed to set. Using a sterile cork borer of $6 \mathrm{~mm}$ diameter, equidistant wells were made in the agar. Drop of the re-suspended, $(2 \mathrm{ml}$ per well) extracts with concentration between $100 \mathrm{mg} / \mathrm{ml}$ to $12.5 \mathrm{mg} / \mathrm{ml}$ were introduced into the wells till it was filled. Levofloxacin $50 \mathrm{mg} / \mathrm{ml}$ was used as the control experiment. The plates were allowed to stand on a bench for an hour, to allow per diffusion of the extracts before incubation at $37^{\circ} \mathrm{C}$ for 24 hours. The zone of inhibition was measured to the nearest millimetre $(\mathrm{mm})$ using a standard transparent meter rule. All the experiments were performed in duplicates (Milstone et al., 2010).

\section{Phytochemical Screening of Plant Extract}

The extract was subjected to phytochemical tests of qualitative and quantitative screening for plant secondary metabolites in accordance with (Onwukaeme et al., 2007).

\section{RESULT}

Table 1 shows the data of patients, collected isolates and laboratory codes, specimen Microbact ${ }^{\mathrm{TM}} 24 \mathrm{E}$ code, percentage of the organism and identified organisms. Isolates collected were identified with Microbact ${ }^{\mathrm{TM}}$ 24E identification kit which is incorporated with different biochemical tests like indole, catalase, citrate, urease, lysine, hydrogen sulphide, gelatin, malonate, inositol, sorbitol, rhamnose, arabinose, raftinose, orninine, salicine, arginine, glucose, mannitol, xylose, sucrose, lactose, ONPG, VP, and TDA.

Table 2 shows the diameter (in $\mathrm{mm}$ ) of the zone of inhibition of the conventional antibiotics against the tested isolates. All the isolates were resistant to ceftazidime, oxacillin, vaconmycin, cefoxitin, piperacillin, amoxicillin, and tazobactam, while $50 \%$ of the isolates were susceptible to imipenem, and ofloxacin. The Proteus mirabilis isolates are susceptible to imipenem with the following diameter $26 \mathrm{~mm}, 24 \mathrm{~mm}, 41 \mathrm{~mm}$ and $20 \mathrm{~mm}$; Samonella subtilis was susceptible to imipenem with diameter of $26 \mathrm{~mm}$; Enterobacter agglomerans was susceptible to imipenem with diameter of $26 \mathrm{~mm}$; Enterobacter gergoviae was susceptible to imipenem with the diameter of $30 \mathrm{~mm}$; Serratia marcescens was susceptible to imipenem with the diameter of $17 \mathrm{~mm}$; Proteus luminescence are susceptible to imipenem with diameter $19 \mathrm{~mm}$. Proteus mirabilis isolates were susceptible to ofloxacin with the diameter of $16 \mathrm{~mm}$, $25 \mathrm{~mm}, 21 \mathrm{~mm}$ and $33 \mathrm{~mm}$; Samonella subtilis were susceptible to ofloxacin with the diameter of $23 \mathrm{~mm}$; Enterobacter agg/omerans were susceptible to ofloxacin with the diameter of $33 \mathrm{~mm}$ and $31 \mathrm{~mm}$; Enterobacter gergoviae was susceptible to ofloxacin with the diameter of $21 \mathrm{~mm}$; Serratia rubidaea is susceptible to ofloxacin with the diameter of $23 \mathrm{~mm}$; Proteus /uminescens is susceptible to ofloxacin with the of diameter $25 \mathrm{~mm}$.

Table 1. Identification of microorganisms using microbact $24 \mathrm{E}$ and their clinical details.

\begin{tabular}{|c|c|c|c|c|c|}
\hline $\mathbf{S} / \mathbf{N}$ & $\begin{array}{l}\text { Lab } \\
\text { code }\end{array}$ & $\begin{array}{c}\text { Specim } \\
\text { en }\end{array}$ & $\begin{array}{l}\text { Result } \\
\text { code }\end{array}$ & $\begin{array}{c}\text { Percenta } \\
\text { ge } \\
\text { probabili } \\
\text { ty }\end{array}$ & Probable organism \\
\hline 1 & D1 & Stool & $\begin{array}{c}1673610 \\
4\end{array}$ & $94.56 \%$ & Proteus vulgaris \\
\hline 2 & D2 & Stool & $\begin{array}{c}5016600 \\
0\end{array}$ & $88.70 \%$ & $\begin{array}{c}\text { Stenotrophomonas } \\
\text { maltophilia }\end{array}$ \\
\hline 3 & D3 & Stool & $\begin{array}{c}7076622 \\
1\end{array}$ & $98.97 \%$ & Hafnia alvei \\
\hline 4 & D4 & Stool & $\begin{array}{c}7057700 \\
0\end{array}$ & $94.86 \%$ & Serratia marcescens \\
\hline 5 & D5 & Stool & $\begin{array}{c}7476406 \\
0\end{array}$ & $80.58 \%$ & Proteus mirabilis \\
\hline 6 & D6 & Stool & $\begin{array}{c}5356616 \\
6\end{array}$ & $76.98 \%$ & Serratia rubidaea \\
\hline 7 & D7 & Stool & $\begin{array}{c}1257620 \\
1\end{array}$ & $90.76 \%$ & $\begin{array}{l}\text { Enterobacter } \\
\text { agglomerans }\end{array}$ \\
\hline 8 & D8 & Stool & $\begin{array}{c}3676611 \\
1\end{array}$ & $84.01 \%$ & Proteus mirabilis \\
\hline 9 & D9 & Stool & $\begin{array}{c}3457612 \\
3\end{array}$ & $99.99 \%$ & Proteus mirabilis \\
\hline 10 & D10 & Stool & $\begin{array}{c}1677630 \\
2\end{array}$ & $92.68 \%$ & $\begin{array}{l}\text { Enterobacter } \\
\text { agglomerans }\end{array}$ \\
\hline 11 & D11 & Stool & $\begin{array}{c}1037600 \\
1\end{array}$ & $75.56 \%$ & Proteus mirabilis \\
\hline 12 & D12 & Stool & $\begin{array}{c}1036466 \\
0\end{array}$ & $81.01 \%$ & Citrobacter freundii \\
\hline 13 & D13 & Stool & $\begin{array}{c}5006400 \\
1\end{array}$ & $92.10 \%$ & $\begin{array}{c}\text { Stenotrophomonas } \\
\text { maltophilia }\end{array}$ \\
\hline 14 & D14 & Stool & $\begin{array}{c}1437610 \\
2\end{array}$ & $99.86 \%$ & Proteus vulgaris \\
\hline 15 & D15 & Stool & $\begin{array}{c}7256602 \\
5\end{array}$ & $72.54 \%$ & Enterobacter gergoviae \\
\hline 16 & D16 & Stool & $\begin{array}{c}6256612 \\
1\end{array}$ & $89.76 \%$ & Serratia rubidaea \\
\hline
\end{tabular}




\begin{tabular}{cccccc}
\hline 17 & D17 & Stool & $\begin{array}{c}7477634 \\
1\end{array}$ & $96.76 \%$ & Ptoteus mirabilis \\
\hline 18 & D18 & Stool & $\begin{array}{c}7777672 \\
1\end{array}$ & $97.86 \%$ & Salmonella subtilis \\
\hline
\end{tabular}

\begin{tabular}{cccccc}
\hline 19 & D19 & Stool & $\begin{array}{c}1036600 \\
0\end{array}$ & $94.78 \%$ & Proteus luminescens \\
\hline 20 & D20 & Stool & $\begin{array}{c}3757617 \\
1\end{array}$ & $91.42 \%$ & Proteus mirabilis \\
& & & &
\end{tabular}

Table 2. Susceptibility test result of the test organisms.

\begin{tabular}{|c|c|c|c|c|c|c|c|c|c|}
\hline \multirow{2}{*}{$\begin{array}{l}\text { Enteropathogenic bacteria } \\
\qquad \begin{array}{l}\mathrm{N}=\mathbf{2 0} \\
\end{array}\end{array}$} & \multicolumn{9}{|c|}{ Antibiotics } \\
\hline & IPM & OFX & CAZ & ox & VA & TZP & AMC & FOX & PRL \\
\hline Proteus vulgaris & 0 & 0 & 0 & 0 & 0 & 0 & - & - & - \\
\hline Stenotrophomonas maltophilia & 0 & 0 & 0 & 0 & 0 & 0 & - & - & - \\
\hline Hafnia alvei & 0 & 0 & 0 & 0 & 0 & 0 & - & - & - \\
\hline Serratia marcescens & 17 & 0 & 0 & 0 & 0 & 0 & - & - & - \\
\hline Proteus mirabilis & 26 & 16 & 0 & 0 & 0 & 0 & - & - & - \\
\hline Serratia rubidaea & 0 & 0 & 0 & 0 & 0 & 0 & - & - & - \\
\hline Enterobacter agglomerans & 22 & 33 & 0 & 0 & 0 & 0 & - & - & - \\
\hline Proteus mirabilis & 24 & 25 & 0 & 0 & 0 & 0 & - & - & - \\
\hline Proteus mirabilis & 41 & 21 & 0 & 0 & 0 & 0 & - & - & - \\
\hline Enterobacter agglomerians & 26 & 31 & 0 & 0 & 0 & 0 & - & - & - \\
\hline Proteus mirabilis & 0 & 0 & 0 & 0 & 0 & 0 & - & - & - \\
\hline Citrobacter freundii & 0 & 0 & 0 & 0 & 0 & 0 & - & - & - \\
\hline Serratia maltophilia & 0 & 0 & 0 & 0 & 0 & 0 & - & - & - \\
\hline Proteus vulgaris & 0 & 0 & 0 & 0 & 0 & 0 & - & - & - \\
\hline Enterobacter gergoviae & 30 & 21 & 0 & 0 & 0 & 0 & - & - & - \\
\hline Serratia rubidaea & 0 & 23 & 0 & 0 & 0 & 0 & - & - & - \\
\hline Proteus mirabilis & 0 & 0 & - & 0 & - & - & 0.0 & 0 & 0 \\
\hline Proteus luminescence & 19 & 25 & - & 0 & - & - & 0 & 0 & 0 \\
\hline Proteus mirabilis & 20 & 33 & - & 0 & - & - & 0 & 0 & 0 \\
\hline
\end{tabular}

OFX=Ofloxacin $(5 \mu \mathrm{g})$ TZP=Tazobactam $(110 \mu \mathrm{g})$ VA=Vancomycin $(30 \mu \mathrm{g})$ 0.0=No Inhibition FOX=Cefoxitin $(30 \mu \mathrm{g})$ AMC=Amoxillin $(30 \mu \mathrm{g})$ CAZ=Ceftazidime $(30 \mu \mathrm{g})$ IPM=Imipenem $(10 \mu \mathrm{g})$ PRL=Piperacillin $(100 \mu \mathrm{g})$ OX=Oxacillin $(1 \mu \mathrm{g})$ 


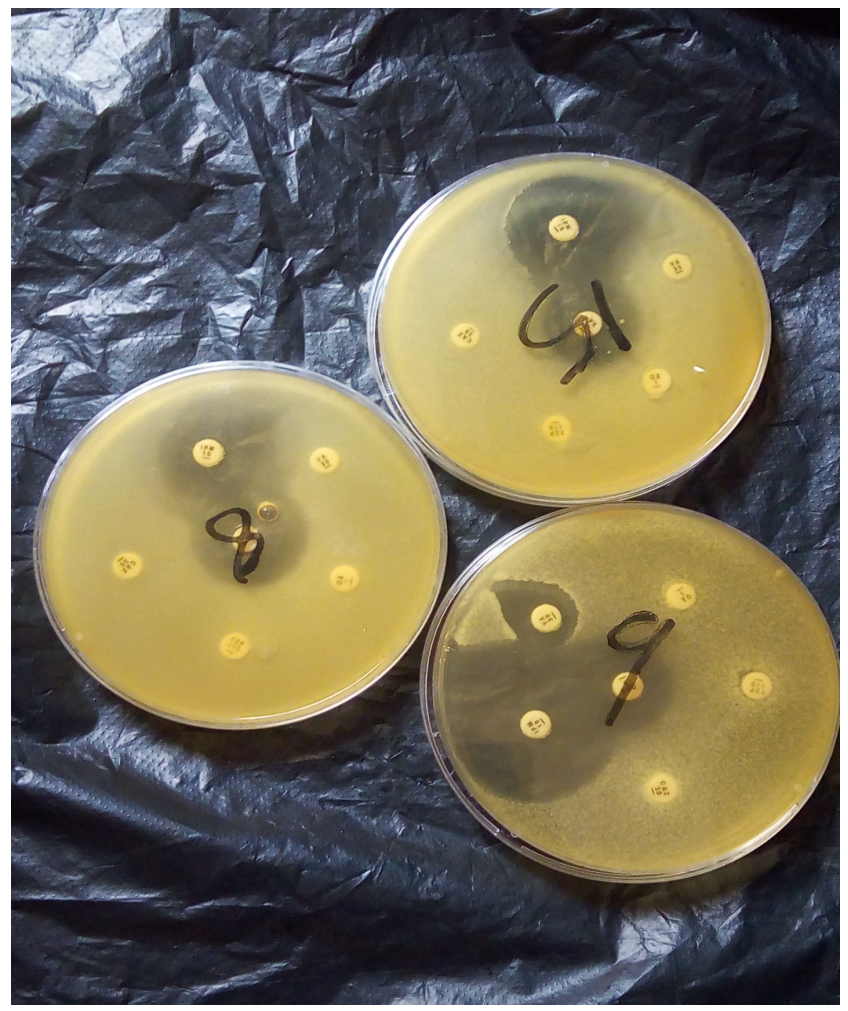

Figure 3. Antibiotic susceptibility test.
Table 3 shows the antimicrobial activity of ethanol extract of Ageratum conyzoides leaf against test enteropathogenic organisms at different concentrations $(100,50,25,12.5 \mathrm{mg} / \mathrm{ml}$, and Control $5 \mathrm{~mm} / \mathrm{ml}$ levofloxacin) measured in diameter $(\mathrm{mm})$. Proteus vulgaris shows the susceptibility diameter zone of inhibition of $22.0 \mathrm{~mm}$ at $100 \mathrm{mg} / \mathrm{ml}, 20.0 \mathrm{~mm}$ at 50 $\mathrm{mg} / \mathrm{ml}, 18.0 \mathrm{~mm}$ at $25 \mathrm{mg} / \mathrm{ml}, 12.0 \mathrm{~mm}$ at 12.5 $\mathrm{mg} / \mathrm{ml}$; Enterobacter agg/omerans showed the susceptibility diameter zone of inhibition of $22.0 \mathrm{~mm}$ at $100 \mathrm{mg} / \mathrm{ml}, 17.0 \mathrm{~mm}$ at $50 \mathrm{mg} / \mathrm{ml}, 15.0 \mathrm{~mm}$ at 25 $\mathrm{mg} / \mathrm{ml}, 10.0 \mathrm{~mm}$ at $12.5 \mathrm{mg} / \mathrm{ml}$; Proteus mirabilis isolates shows the susceptibility diameter zone of inhibition of $15.0 \mathrm{~mm}, 19.0 \mathrm{~mm}, 18.0 \mathrm{~mm}$ at 100 $\mathrm{mg} / \mathrm{ml}, 15.0 \mathrm{~mm}, 15.0 \mathrm{~mm}, 14.0 \mathrm{~mm}$ at $50 \mathrm{mg} / \mathrm{ml}$, $10.0 \mathrm{~mm}, 15.0 \mathrm{~mm}, 8.0 \mathrm{~mm}$ at $25 \mathrm{mg} / \mathrm{ml}$ and $0.0 \mathrm{~mm}$, $12.0 \mathrm{~mm}, 0.0 \mathrm{~mm}$ at $12.5 \mathrm{mg} / \mathrm{ml}$. Enterobacter agglomerans and Proteus vulgaris were observed to have the highest susceptibility to the leaf extract with $22.0 \mathrm{~mm}$ at $100 \mathrm{mg} / \mathrm{ml}, 17.0 \mathrm{~mm}$ at $50 \mathrm{mg} / \mathrm{ml}, 15.0$ $\mathrm{mm}$ at $25 \mathrm{mg} / \mathrm{ml}, 10.0 \mathrm{~mm}$ at $12.5 \mathrm{mg} / \mathrm{ml}$ and 22.0 $\mathrm{mm}$ at $100 \mathrm{mg} / \mathrm{ml}, 20.0 \mathrm{~mm}$ at $50 \mathrm{mg} / \mathrm{ml}, 18.0 \mathrm{~mm}$ at $25 \mathrm{mg} / \mathrm{ml}, 12.0 \mathrm{~mm}$ at $12.5 \mathrm{mg} / \mathrm{ml}$ diameter zone inhibition. $P$. mirabilis was observed to have the lowest susceptibility to the leaf extract of the plant with diameter $15 \mathrm{~mm}$ at $100 \mathrm{mg} / \mathrm{ml}, 15 \mathrm{~mm}$ at $50 \mathrm{mg} / \mathrm{ml}$, $10 \mathrm{~mm}$ at $25 \mathrm{mg} / \mathrm{ml}$ and $0.0 \mathrm{~mm}$ at $12.5 \mathrm{mg} / \mathrm{ml}$.

Table 3. Antimicrobial activity of ethanol extract of Ageratum conyzoides.

\begin{tabular}{|c|c|c|c|c|c|}
\hline \multirow[t]{2}{*}{ Test Organisms } & \multicolumn{5}{|c|}{ Ethanol extract of Ageratum conyzoides concentration ( $\mathrm{mg} / \mathrm{ml})$} \\
\hline & 100 & 50 & 25 & 12.5 & Levofloxacin $5 \mathrm{mg} / \mathrm{ml}$ \\
\hline Proteus vulgaris & 22 & 20 & 18 & 12 & 31 \\
\hline S. maltophilia & 0 & 0 & 0 & 0 & 0 \\
\hline Hafnia alvei & 0 & 0 & 0 & 0 & 0 \\
\hline S. marcescens & 0 & 0 & 0 & 0 & 0 \\
\hline proteus mirabilis & 15 & 15 & 10 & 0 & 32 \\
\hline Serratia rubidaea & 0 & 0 & 0 & 0 & 0 \\
\hline E. agglomerans & 22 & 17 & 15 & 12 & 31 \\
\hline Proteus mirabilis & 19 & 15 & 15 & 12 & 33 \\
\hline Proteus mirabilis & 18 & 14 & 8 & 0 & 36 \\
\hline E. agglomerans & 0 & 0 & 0 & 0 & 0 \\
\hline Proteus mirabilis & 0 & 0 & 0 & 0 & 0 \\
\hline Citrobacter freundii & 0 & 0 & 0 & 0 & 25 \\
\hline S. maltophilia & 0 & 0 & 0 & 0 & 30 \\
\hline Proteus vulgaris & 0 & 0 & 0 & 0 & 28 \\
\hline E. gergoviae & 0 & 0 & 0 & 0 & 23 \\
\hline Serratia rubidaea & 0 & 0 & 0 & 0 & 0 \\
\hline
\end{tabular}




\begin{tabular}{cccccc}
\hline Proteus mirabilis & 0 & 0 & 0 & 0 & 0 \\
\hline Salmonella subtilis & 0 & 0 & 0 & 0 & 0 \\
\hline P. luminescence & 0 & 0 & 0 & 0 & 32 \\
\hline Proteus mirabilis & 0 & 0 & 0 & 0 & 0 \\
\hline
\end{tabular}

Data are presented as mean of measurement of zone of inhibition of two replicates measured in mm. Zone of inhibition does not include the diameter of the cork borer $(6 \mathrm{~mm})$. Levofloxacin is the control, Key: $0.0=$ No Inhibition.
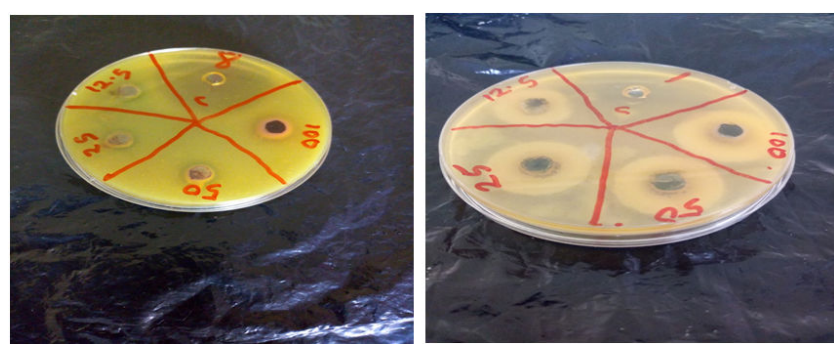

Figure 4. Antimicrobial susceptibility test.

Table 4 shows the minimum inhibitory concentration (MIC) value of the ethanol extract of Ageratum conyzoides leaf against the test organisms used in the study. From this table, E. agglomerans strain was the test organism with the least MIC values at $50 \mathrm{mg} / \mathrm{ml}$ while $P$. mirabilis was the test organism that was inhibited throughout the values measured. $P$. mirablis isolates were the bacteria with the highest MIC value among the bacteria isolates with its MIC value at approximately $100 \mathrm{mg} / \mathrm{ml}$.

Table 5 shows the qualitative phytochemical analysis of Ageratum conyzoides using methanol, ethyl acetate, dichloromethane and acetone solvents. From this table, it was observed that alkaloid cardiac glycoside, phenol, tannins, and saponin were found in all the solvents used. Steroids were absent in acetone while, it was present in dichloromethane, methanol and ethylacetate. The alkaloid, cardiac glycoside, anthraquinone, tannins, saponin constituents were present in all the solvents used. Flavonoids was absent in methanol while present in ethyl-acetate, dichloromethane and acetate and reducing sugar was absent in ethyl-acetate while present in methanol, dichloromethane and acetate.

Table 4. Minimum Inhibitory Concentration of Ethanol Extracts of Ageratum conyzoides.

\begin{tabular}{|c|c|c|c|}
\hline Lab code & $25 \mathrm{mg} / \mathrm{ml}$ & $50 \mathrm{mg} / \mathrm{ml}$ & $100 \mathrm{mg} / \mathrm{ml}$ \\
\hline Proteus vulgaris & + ve & -ve & $-v e$ \\
\hline Proteus mirabilis & + ve & -ve & $-v e$ \\
\hline Enterobacter agglomerians & $+\mathrm{ve}$ & -ve & -ve \\
\hline Proteus mirabilis & $+v e$ & -ve & $-v e$ \\
\hline Proteus mirabilis & -ve & -ve & -ve \\
\hline
\end{tabular}

Key: ve+=Growth observed ve-=No growth observed

Table 5. Qualitative phytochemical analysis of Ageratum conyzoides.

\begin{tabular}{|c|c|c|c|c|}
\hline Phytochemical & Methanol Solvent & Ethyl-acetate solvent & Dichloromethane solvent & Acetone solvent \\
\hline Alkaloid & $+\mathrm{ve}$ & $+\mathrm{ve}$ & + ve & $+\mathrm{ve}$ \\
\hline Cardiac glycolside & $+\mathrm{ve}$ & $+\mathrm{ve}$ & $+\mathrm{ve}$ & $+\mathrm{ve}$ \\
\hline Steroid & $+v e$ & $+\mathrm{ve}$ & \pm ve & -ve \\
\hline Anthraquinone & $+\mathrm{ve}$ & ND & $+\mathrm{ve}$ & $+\mathrm{ve}$ \\
\hline Phenol & $+\mathrm{ve}$ & $+\mathrm{ve}$ & $+\mathrm{ve}$ & $+\mathrm{ve}$ \\
\hline Tannins & $+\mathrm{ve}$ & + ve & $+\mathrm{ve}$ & + ve \\
\hline Saponin & $+\mathrm{ve}$ & $+\mathrm{ve}$ & $+\mathrm{ve}$ & $+\mathrm{ve}$ \\
\hline Flavonoids & -ve & $+\mathrm{ve}$ & $+\mathrm{ve}$ & $+\mathrm{ve}$ \\
\hline Reducing sugar & $+\mathrm{ve}$ & -ve & $+\mathrm{ve}$ & + ve \\
\hline
\end{tabular}

Keys: +ve=Positive - ve=Negative

Table 6 shows the quantitative analysis of the phytochemical constituents of Ageratum conyzoides using four different solvents which are methanol, ethyl- acetate, dichloromethane and acetone, showed the presence of different phytoconstituents in different quantities. For leaf using methanol, alkaloid was 
shown to be present in the largest quantity with 9.10 , and saponin was found to be the least abundantly present with 0.3. The quantitative phytochemical screening of $A$. conyzoides leaf using ethyl acetate, alkaloid was shown to be present in the largest quantity with 11.3 , and cardiac glycoside was found to be the least abundantly present with 0.6. The quantitative phytochemical screening of $A$. conyzoides leaf using dichloromethane (DCM), alkaloid was shown to be present in the largest quantity with 13.8 , and flavonoids was found to be the least abundantly present with 3.21. The quantitative phytochemical screening of $A$. conyzoides leaf using acetone, cardiac glycoside was shown to be present in the largest quantity with 9.71 , and flavonoids was found to be the least abundantly present with 2.90 .

Table 6. Quantitative phytochemical analysis of Ageratum conyzoides.

\begin{tabular}{ccccc}
\hline Phytochemical & $\begin{array}{c}\text { Methanol } \\
\text { Solvent }\end{array}$ & $\begin{array}{c}\text { Ethyl- } \\
\text { acetate } \\
\text { solvent }\end{array}$ & $\begin{array}{c}\text { Dichloromethane } \\
\text { solvent }\end{array}$ & $\begin{array}{c}\text { Acetone } \\
\text { solvent }\end{array}$ \\
\hline Alkaloid & 9.1 & 11.3 & 13.8 & 3.89 \\
\hline Cardiac glycoside & 9.35 & 0.6 & 9.71 & 9.71 \\
\hline Phlobatannins & 3.11 & 7.5 & 14 & 4.01 \\
\hline Phenol & 4.7 & 9.52 & 9.7 & 9.7 \\
\hline Tannins & 7.37 & 0.3 & 7.51 & 7.51 \\
\hline Saponin & 0.32 & 7.34 & 7.6 & 7.6 \\
\hline Flavonoids & 2.71 & 7.23 & 3.21 & 2.9 \\
\hline
\end{tabular}

\section{DISCUSSION}

The aim of this study is to determine the phytochemical composition, antimicrobial properties, and Phenotypic Resistance Pattern of Selected Enteropathogenic microorganism on Ageratum conyzoides leaf extract. For centuries, medicinal plants have been the main source for drugs in many centuries, and it is estimated that at least $25 \%$ of modern medicine are derived either directly or indirectly from medicinal plants (Olajubu et al., 2015, Prasannabalaji et al., 2006). Herbal medicine has been shown to have genuine utility and about $80 \%$ of rural dwellers depend on its efficacy for their primary health care. Medicinal plants contribute an effective source of both traditional and modern medicines (Ram et al., 2008).

Ageratum conyzoidesis commonly found in the rain forest region of Nigeria, along with other plants with good medicinal properties has plays a significant role in the eradication of Enteropathogenic Microorganism causing Gastroenteritis (Onwukaeme et al., 2007, Ram et al., 2008). In this study, the leaf of Ageratum conyzoidesis plant were extracted using ethanol, and were tested for their antibacterial properties against
Proteus vulgaris, Stenotrophomonas maltophilia, Hafnia alvei, Proteus mirabilis, serratia marcescens, Enterobacter agglomerans, Serratia rubidaea, Enterobacter gergoviae, Proteus luminescence, Salmonella subtilis, and Citrobacter freundii.

Gastroenteritis caused by Enteropathogenic microorganism is one of the most popular sicknesses among children and can be caused by many infectious agents, varying from bacteria, parasites and viruses, whose etiology and prevalence varies among developing and developed countries. However, patients may show more severe symptoms ranging from relatively mild upper gastroenteritis symptoms, such as nausea and vomiting, to severe symptoms, such as profuse diarrhoea that leads to dehydration or death (Osuntokun et al., 2015). Each year, an estimated 2.5 billion cases of diarrhoea occurs among children under five years of age, and estimates suggest that overall incidence has remained relatively stable over the past two decades. Infectious diarrhoea affects mainly children who are at risk of complications, especially when they suffer from malnutrition, which is common in Palestinian children (Olajubu et al., 2015, Oyedele et al., 2006). The crude plants extract tested in this study showed antimicrobial activities against Proteus vulgaris, Enterobacter agglomerans and Proteus mirabilis isolates with diameter zone of inhibition of $22.0 \mathrm{~mm}$ at $100 \mathrm{mg} / \mathrm{ml}, 20.0 \mathrm{~mm}$ at $50 \mathrm{mg} / \mathrm{ml}, 18.0$ $\mathrm{mm}$ at $25 \mathrm{mg} / \mathrm{ml}, 12.0 \mathrm{~mm}$ at $12.5 \mathrm{mg} / \mathrm{ml} ; 22.0 \mathrm{~mm}$ at $100 \mathrm{mg} / \mathrm{ml}, 17.0 \mathrm{~mm}$ at $50 \mathrm{mg} / \mathrm{ml}, 15.0 \mathrm{~mm}$ at 25 $\mathrm{mg} / \mathrm{ml}, 10.0 \mathrm{~mm}$ at $12.5 \mathrm{mg} / \mathrm{ml}$; and $15.0 \mathrm{~mm}, 19.0$ $\mathrm{mm}, 18.0 \mathrm{mmat} 100 \mathrm{mg} / \mathrm{ml}, 15.0 \mathrm{~mm}, 15.0 \mathrm{~mm}, 14.0$ $\mathrm{mm}$ at $50 \mathrm{mg} / \mathrm{ml}, 10.0 \mathrm{~mm}, 15.0 \mathrm{~mm}, 8.0 \mathrm{~mm}$ at 25 $\mathrm{mg} / \mathrm{ml}, 10.0 \mathrm{~mm}, 12.0 \mathrm{~mm}, 0.0 \mathrm{~mm}$ at $12.5 \mathrm{mg} / \mathrm{ml}$. However, differences were observed between their antimicrobial activities.

Ethanol extract of Ageratum conyzoides is leaf, as observed from this study, can be a source of a novel antimicrobial agent, especially with good activities against organisms like Proteus vulgaris (Raquel 2007). The minimum inhibitory concentration of the extract range from $25 \mathrm{mg} / \mathrm{ml}$ to $100 \mathrm{mg} / \mathrm{ml}$. Minimum inhibitory concentration (MIC) is the lowest concentration of an antimicrobial (antibiotic or bacteriostatic, antifungal) drug that will inhibit the visible growth of a microorganism after overnight incubation (Tripathi et al., 2013).

The quantitative phytochemical screening of Ageratum conyzoides leaf using different solvents, showed the presence of different phytoconstituents in different quantities. For leaf using methanol, alkaloid was shown to be present in the largest quantity with 9.10 , and saponin was found to be the least abundantly present with 0.3. The quantitative phytochemical screening of $A$. conyzoides leaf using ethyl acetate, alkaloid was shown to be present in the largest 
quantity with 11.3 , and cardiac glycoside was found to be the least abundantly present with 0.6. The quantitative phytochemical screening of $A$. conyzoides leaf using dichloromethane (DCM), alkaloid was shown to be present in the largest quantity with 13.8 , and flavonoids was found to be the least abundantly present with 3.21. The quantitative phytochemical screening of $A$. conyzoides leaf using acetone, cardiac glycoside was shown to be present in the largest quantity with 9.71 , and flavonoids was found to be the least abundantly present with 2.90 (Table 6) (Trease et al., 2006, Wang et al., 2002).

The qualitative phytochemical screening of $A$. conyzoides contains alkaloid, flavonoid, tannins, and saponin, reducing sugars, steroids, phenol, cardiac glycoside and anthraquinone (Table 5). These biologically active constituent is known to act by different mechanism and exert antimicrobial action (WHO 2005). Alkaloids are medicinally useful, possessing analgesic, antispasmodic and bactericidal effects. Flavonoids are hydroxylated phenolic substance known to be synthesized by plants in response to microbial infection and it should not be surprising that they have been found in vitro to be effective antimicrobial substances against a wide array of microorganisms. Their activity is probably due to their ability to complex with extracellular and soluble proteins and to complex with bacterial cell walls (Wang et al., 2002).

The antimicrobial property of saponin is due to its ability to cause leakage of proteins and certain enzymes from the cell (Trease et al., 2006). Steroids have been reported to have antibacterial properties the correlation between membrane lipids and sensitivity for steroidal compound indicates the mechanism in which steroids specifically associate with membrane lipid and exerts its action by causing leakages from liposomes(Xuan et al., 2004).These differences could be attributed to the differences in their chemical composition and amount of the bioactive compounds extracted by the solvent. These compounds usually accumulate in different parts of the plants (Tripathi et al., 2013). Proteus vulgaris was observed to be the most susceptible organism to the ethanol extract of Ageratum conyzoidesis leaf with diameter zone of inhibition of $22 \mathrm{~mm}$ at $100 \mathrm{mg} / \mathrm{ml}$ while Proteus mirabilis was seen to be the least susceptible to this extract with diameter zone of inhibition of $15 \mathrm{~mm}$ at $100 \mathrm{mg} / \mathrm{ml}$ respectively as shown in Table 3. The greater abundance of the dichloromethane (DCM) extract of $A$. conyzoides leaf could indicate that, the crude dichloromethane (DCM) extract possess antimicrobial properties than any others extracts of this same plant.

The importance of Ageratum conyzoides must be mentioned in order to encourage its uses. Ageratum conyzoides is used as an infusion with the leave or the entire plant; this is employed in the treatment of colic, fever, diarrhoea, rheumatism and spasms. It can also be used as blood tonic (Xuan et al., 2004).it is highly employed in the treatment of burns and infected wound. In some country like Nigeria, the plant can be used as antibiotics because of its antimicrobial properties and various clinical microorganism especially the enteropathogenic microbes and infection (Akubugwo et al., 2006).

\section{CONCLUSION}

Plants are found in nearly all the regions of the world. The prevailing climatic, soil and environmental conditions often play a vital role in determining the type of plant species that could be found in such region. Due to the challenges associated with drug resistance, which have made scientists to search for effective and sustainable means of managing the problem. Plants have emerged as an alternative to synthetic antibiotics which is prone to reoccurring drug resistance. The result of antimicrobial susceptibility assay showed promising evidence for the antimicrobial effects of $A$. conyzoides against bacterial Proteus vulgaris, Enterobacter agglomerans, and Proteus mirabilis isolates used in this study. The MIC value of different organisms are verified, and thus, MIC are assays capable of verifying that the compound has antimicrobial activities, and that it gives reliable indication of the concentration of medicine required to inhibit the growth of microorganisms. Phytochemical analysis is responsible for the identification of components which are responsible for antimicrobial activity of plant, thus these traditional species can be used as a potential source of medicine against various diseases.

\section{REFERENCES}

Adak G, Long S, O'Brien S (2002). Trends in indigenous food borne disease and death. England and Wales: 1992 to 2000. Gut. 51:832-841.

Akinyemi KO, Oladapo O, Okwara CE, Ibe CC, Fasure KA (2005).Screening of crude extracts of six medicinal plants used in South-West Nigerian unorthodox medicine for anti-methicilin resistant Staphylococcus aureus activity. BMC Complementary and Alternative Medicine. 5: 6.

Chanda SV, Parekh J, Karathia N (2006). Evaluation of antibacterial activity and phytochemical analysis of Bauhinia variegate L. bark. African Journal of Biomedical Research.9:53-56.

Dandekar T, Dandekar G (2010).Pharmacogenomic strategies againstmicrobial resistance: from bright to bleak to innovative. Pharmacogenomics. 11:1193-1196. 
Dahiru D, Onubiyi JA, Umaru HA (2006). Phytochemical screening and antiulcerogenic effect of Mornigo oleifera aqueous leaf extract. African Journal Of Traditional, Complementary and Alternative Medicines.3: 70-75.

Durodola JJ (2006). Antibacterial property of crude extracts from herbal wound healing remedy Ageratum conyzoides, L. Planta Medica. 32:388-390.

Edeoga HO, Okwu DE, Mbaebie BO (2005). Phytochemical constituents of some Nigerian medicinal plants. African Journal of Biotechnology. 4: 685-688.

Hazra KM, Roy RN, Sen SK, Laska S (2007). Isolation of antibacterial pentahydroxy flavones from the seeds of Mimusops elengi Linn. African Journal of Biotechnology. 6: 1446-1449.

Kamboj A, Saluja AK (2008). Ageratum conyzoides L.: a review on its phytochemical and pharmacological profile. International Journal of Green Pharmacy. 2:59-68.

Kumar GS, Jayaveera KN, Kumar CKA, Sanjay UP, Vrushabendra Swamy BM, Kumar DV (2007). Antimicrobial effects of Indian medicinal plants against acne-inducing bacteria. Tropical Journal of Pharmaceutical Research.6: 717- 723.

Mcarvalho C, Gannon B, Halfhide D, Santos S, Hayes C, Roe J, Azeredo J (2010). The in vivo efficacy of two administration routes of a phage cocktail to reduce numbers of Campylobacter jejuni and Campylobacter coli in chickens. BMC Microbiology.10:232.

Metchock B, Lonsway D, Carter G, Lee LA, McGowan JE (2011). Yersinia enterocolitica: a frequent seasonal stool isolate from children at an urban hospital in the Southeast United States. Journal of Clinical Microbiology.29:2868-2869.

Milstone AM, Bryant KA, Huskins WC, Zerr DM (2010).The past, present and future of health careassociated infection prevention in pediatrics: Multidrug resistant organisms. Infection Control and Hospital Epidemiology. 31 suppl 1:518-21.

Onwukaeme DN, Ikuegbvweha TB, Asonye CC (2007). Evaluation of phytochemical constituents, antibacterial activities and effect of exudates of Pycanthus angolensis Weld Warb (Myristicaceae) on corneal ulcers in rabbits. Tropical Journal of Pharmaceutical Research. 6: 725-730.

Osuntokun OT (2015). Comperative Study of Antibacterial and Phytochemical Properties of
Nigerian Medicinal Plants on Salmonella bongori and Samonella enerititis isolated from Poultry Faeces in Owo Local Government. Ondo State, Nigeria. Archives of Current Research International. 2:1-11.

Osuntokun OT, Olajubu FA (2015). Antibacterial and phytochemical properties of some Nigerian medicinal plant on salmonella paratyphi isolated from infected human stool in Owo local government. Journal of Scientific Research and Report. 4:331-449. Article no. JSSR. 2015. 046.

Okwori A, Dina C, Junaid S, Okeke I, Adetunji J, Olabode A (2006). Antibacterial activities of Ageratum conyzoides extracts on selected bacterial pathogen. The Internet Journal of Microbiology. 4:1-5. Prasannabalaji N, Muralitharan G, Sivanandan RN, Kumaran S, Pugazhvendan SR (2012). Antibacterial activity of some Indian traditional plants extracts. Asian Pacific Journal of Pacific Disease. S251-S259.

Ram PK, Crump JA, Gupta SK, Miller MA, Mintz ED (2008). Part ii. Analysis of data gaps pertaining to shigella infections in low and medium development index countries, 1984-2005. Epidemiology and Infection. 136:577-603.

Raquel FE, Savage PB, Epand RM (2007). Bacterial lipid composition and the antimicrobial efficacy of cationic steroid compounds (Ceragenins). Biochimica et Biophysica Acta. 1768:2500-9.

Tripathi KD (2013). Essentials of Medical Pharmacology (7th ed.). New Delhi, India: Jaypee Brother Medical Publishers. Pp. 696,697.

Trease GE, Evans WC (1989). Pharmacognosy.13th edition. Bailliere Tinall Ltd. London.

Wang ZG, Ren J (2002).Current status and future direction of Chinese herbal Medicine.Trends in Pharmacological Sciences. 23: 347-348.

WHO (2005). Guidelines for the control of shigellosis, including epidemics due to Shigella dysenteriae type 1. Geneva, Switzerland, p:2.

Xuan TD, Shinkichi T, Hong NH, Khanh TD, Min CI (2004). Assessment of phytotoxic action of Ageratum conyzoides L. (billy goat weed) on weeds. Crop Protection. 23: 915-922.

Akubugwo EI, Arukwe UI, Chinyere GC (2006). A practical work-book on acid-base chemistry and qualitative analysis of biomacromolecules. 2nd edition, Research and Academic Publishers, Imo State, Nigeria. pp.193-215. 